Citation: E. Kopilov, H. Tsekhmister, O. Nadkernychna, A. Kyslynska (2021) Identification of Plectosphaerella melonis from cucumber plants in Ukraine. Phytopathologia Mediterranea 60(2): 259-263. doi: 10.36253/phyto-12612

Accepted: June 14, 2021

Published: September 13, 2021

Copyright: (c) 2021 E. Kopilov, H. Tsekhmister, O. Nadkernychna, A. Kyslynska. This is an open access, peerreviewed article published by Firenze University Press (http://www.fupress. $\mathrm{com} / \mathrm{pm}$ ) and distributed under the terms of the Creative Commons Attribution License, which permits unrestricted use, distribution, and reproduction in any medium, provided the original author and source are credited.

Data Availability Statement: All relevant data are within the paper and its Supporting Information files.

Competing Interests: The Author(s) declare(s) no conflict of interest.

Editor: Josep Armengol Forti, Polytechnical University of Valencia, Spain.

\section{Short Notes \\ Identification of Plectosphaerella melonis from cucumber plants in Ukraine}

\author{
Evgeniy KOPILOV, Hanna TSEKHMISTER*, Olena NADKERNYCHNA, \\ ANNA KYSLYNSKA \\ Laboratory of plant microbial interaction, Institute of Agricultural Microbiology and \\ Agro-industrial Manufacture, National Academy of Agrarian Sciences of Ukraine \\ (NAAS), Chernihiv, Ukraine \\ *Corresponding author. E-mail: anna.tceh@gmail.com
}

Summary. A fungus was isolated from diseased roots of Cucumis sativus grown in greenhouses. The morphological and cultural characteristics of the isolate allowed it to be classified as Plectosphaerella melonis. BLASTn analysis revealed 99\% homology of the ITS sequence from the isolate with 14 Acremonium cucurbitacearum and P. melonis isolates, allowing attribution of the isolate to P. melonis (syn. A. cucurbitacearum). Koch's hypothesis requirements were fulfilled for the isolate. Symptoms on host roots developed after $14 \mathrm{~d}$ of growing cucumber plants on infested soil. Plants of the cucumber variety Nizhynskyi 12 were very susceptible at the two leaf growth stage (2 weeks after sowing). Above-ground disease symptoms were absent after $14 \mathrm{~d}$, even with severely diseased roots. This is the first report of P. melonis on C. sativus in Ukraine.

Keywords. Acremonium cucurbitacearum, cucurbits, disease, identification, pathogen, Plectosphaerella melonis, soilborne.

\section{INTRODUCTION}

Plectosphaerella spp. are known pathogens for a wide range of agricultural crops, including Cucurbitaceae (Carlucci et al., 2012; Raimondo and Carlucci, 2018a; 2018b).

In Spain, Alfaro-García et al. (1996) reported that the causal agent of this disease, after the mass death of melons at the beginning of fruit ripening, was the fungus Acremonium cucurbitacearum. Bruton et al. (1996) described the same disease on melon plants in Texas (United States of America). Carlucci et al. (2012) determined that A. cucurbitacearum was synonymous to Nodulisporium melonis and transferred the pathogen to Plectosphaerella as $P$. melonis comb. nov.

A Plectosphaerella species was consistently isolated from diseased cucumber plants grown in a greenhouse in Ukraine. The aim of the present study was to identify the isolate fungus using morphological cultural and molecular genetic characteristics, and to confirm its pathogenicity to Cucumis sativus. 


\section{MATERIALS AND METHODS}

Plant sampling and fungus isolation

A fungus isolate (coded 502) was collected from affected roots of $C$. sativus (variety Koroliok), at the mass fruiting stage of crop growth. Cucumis sativus was grown in greenhouses in Chernihiv district, Chernihiv region (Ukraine). Affected host root segments (3-5 $\mathrm{mm}$ ) were thoroughly washed for $15 \mathrm{~min}$ under running water, surface sterilized with $96 \%$ ethyl alcohol for 1 min then washed twice with sterile water, and were then plated into Petri dishes containing 4\% barley meal agar (BMA) amended with $250 \mathrm{ppm}$ streptomycin. The plates were incubated at $26^{\circ} \mathrm{C}$, and after $4 \mathrm{~d}$ the resulting fungus was reisolated onto BMA.

\section{Morphological identification}

The cultural and morphological characteristics of the isolated fungus were examined after culture on BMA, Czapek's agar (CZA) or potato dextrose agar (PDA) in the darkness at $26^{\circ} \mathrm{C}$. After $10 \mathrm{~d}$ in culture, the fungus completely covered the agar surfaces, and colonies were characterised.

\section{Temperature/growth relationship}

The temperature optimum for the isolated fungus was studied by culturing the fungus in Petri dishes on BMA at $10,18,26$ or $35^{\circ} \mathrm{C}$. After $10 \mathrm{~d}$, the colony diameters were measured in two mutually perpendicular directions, and colony radial growth rates were determined (Pert, 1978).

\section{Molecular identification}

DNA extraction. For DNA isolation, parts of fungus colonies grown on BMA were processed using the AmpliSens DNA-sorb-B kit. The necessary quantity of DNA solution obtainment was carried out in appliance to described methods (Birnboim \& Doly, 1979; Chowdhury \& Akaike, 2005; Chi et al., 2009; Sika et al., 2015).

PCR analysis. For sequencing, obtained DNA solution polymerase chain reaction was carried out using ITS1 and ITS4 primers (White et al., 1990). The amplification reaction was conducted within Applied Biosystems equipment following prescribed methods (Watts \& MacBeath, 2001; Garrido et al., 2009). Analysis of resulting 5.8S rDNA sequences were compared with GenBank database sequences using by BLAST analyses (http:// www.ncbi.nlm.nih.gov/blast).

\section{Pathogenicity test}

Pathogenicity tests were performed in a pot experiment using $C$. sativus plants (var. Nizhynskyi 12). Pots (2 L capacity) were each filled with $1800 \mathrm{~g}$ of soil which had been previously steamed at $70-80^{\circ} \mathrm{C}$ for $50 \mathrm{~min}$.

Inoculum of the isolated fungus was prepared by growing the fungus on medium containing oat seeds, oat flakes, water, chalk and gypsum in $1 \mathrm{~L}$ capacity flasks. This substrate was sterilized twice at $128^{\circ} \mathrm{C}$ and 1.5 atm pressure for $1 \mathrm{~h} 30 \mathrm{~min}$, and was then inoculated with pure cultures of the isolate, grown in tubes containing BMA. The flasks were kept at $26^{\circ} \mathrm{C}$ for $21 \mathrm{~d}$. Than the inoculum was transferred into paper bags, dried to constant weight at $30{ }^{\circ} \mathrm{C}$, and mixed with soil.

Cucumis sativus seeds were sown to a depth of $2 \mathrm{~cm}$. Fungus inoculum was applied to the pots at the equivalent of $5 \times 10^{4} \mathrm{CFU} \mathrm{g} \mathrm{g}^{-1}$ of soil (Bruton et al., 2000a). Experimental controls were cucumber plants grown without added inoculum. Soil in the pots was maintained at $60 \%$ of total water holding capacity. The pots were placed randomly in a greenhouse with natural lighting. The experiment was repeated five times. After emergence of the cucumber seedlings, these were thinned to five per pot. After 2 and 4 weeks, the plants were removed, washed from the soil and the root systems were evaluated.

Root segments (3-5 $\mathrm{mm}$ each) were thoroughly washed for 15 min under running water, surface sterilized with $96 \%$ ethyl alcohol for $1 \mathrm{~min}$, and then washed twice with sterile water. The segments were then placed into Petri dishes containing 4\% BMA plus $250 \mathrm{ppm}$ Streptomycin at $26^{\circ} \mathrm{C}$, and after $4 \mathrm{~d}$ the resulting fungus was reisolated onto BMA.

\section{Statistical analyses}

The data obtained were analyzed using Statistica 12. Normality of the data were assessed using Shapiro-Wilks W-test statistics, and homogeneity of variances was assessed using the Brown-Forsythe test. The nonparametric Mann-Whitney $U$ test was applied $(P \leq 0.05)$ to compare experimental groups, including fungus growth media. One-way Analysis of Variance (ANOVA) and Duncan Multiple Range Tests were used to determine optimum temperature. 


\section{RESULTS AND DISCUSSION}

Isolate 502 was obtained from affected cucumber plants grown in greenhouses (Figure 1a). Disease symptoms were absent until the onset of the mass plant fruiting phase of cucumber. The symptoms included fading of leaf edges on the lower leaves of affected plants. The root systems had secondary and tertiary roots with necrotic areas (Figure 1b). No reductions in plant growth or delays in development were observed.

The macro-morphological features of isolate 502 differed depending on the culture medium (Figure 2). Colonies were rounded, hyphae were thin, septate and hyaline. The colonies on PDA were white or cream, the colony surfaces were and velvety. On BMA, the colony colours varied from white to rose pink. On CZA the colonies had white aerial mycelium. Colonies had radial wrinkles on the reverse sides, and the colonies were slow-growing (Table 1), the most rapid growth was on PDA.

Phialides of isolate 502 were unbranched, septate, mostly simple, and measured from $22.4 \times 4.2 \mu \mathrm{m}$ to $42.0 \times 4.2 \mu \mathrm{m}$. The phialides were coloured along their entire lengths. The phialides were located on hyphal filaments and each had a basal septum at the base. Unicellular conidia were assembled into a head at the apex of each phialide. Conidia were oblong, elliptical, smoothwalled and hyaline (granular). Conidia in PDA cultured measured $8.4 \times 2.8 \mu \mathrm{m}$ to $14.0 \times 2.8 \mu \mathrm{m}$, and sporulation was most intense on this medium. On BMA, the conidia were smaller $(5.6 \times 3.1 \mu \mathrm{m}$ to $11.2 \times 2.8 \mu \mathrm{m})$ and sporulation was intense. On CZA, sporulation was not intense and the conidia were $4.2 \times 4.2 \mu \mathrm{m}$ to $8.4 \times 4.2 \mu \mathrm{m}$. Chlamydospores were absent. These characteristics were similar to those described for P. melonis (Alfaro-Garcia et al., 1996; Carlucci et al., 2012).
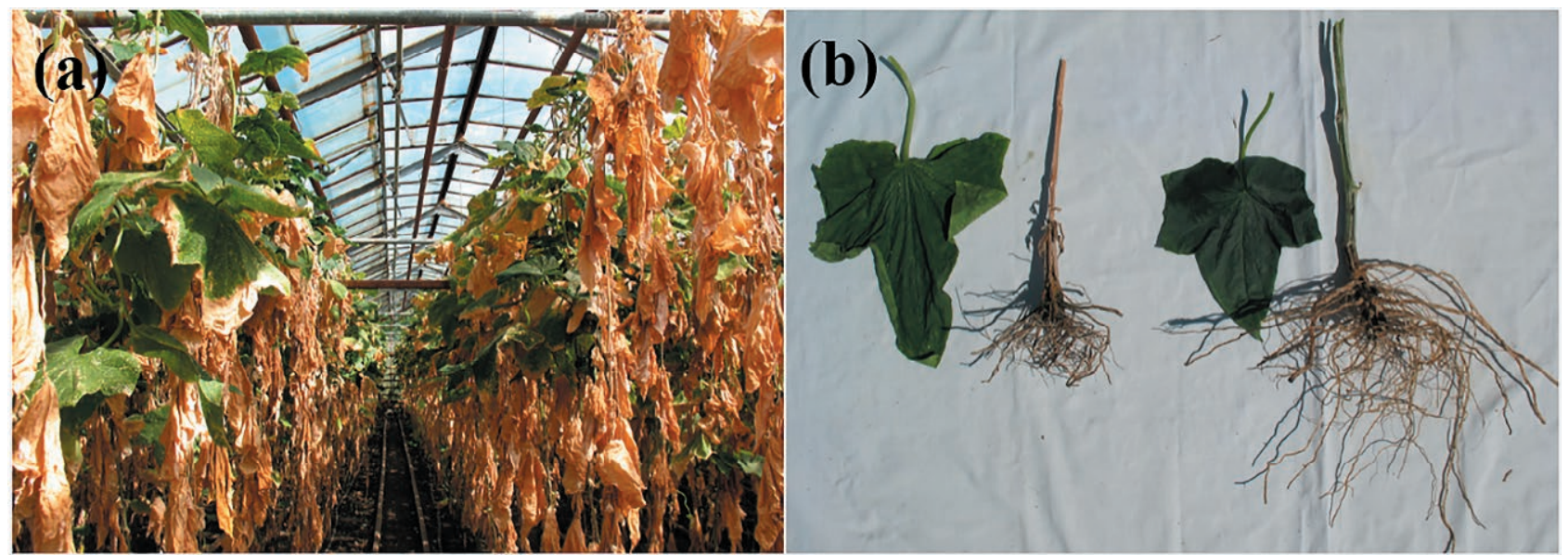

Figure 1. (a) Cucumber plants (variety Koroliok) affected by Plectosphaerlla melonis (isolate 502) in a greenhouse. (b) Leaf and root of an affected plant (left) and a healthy plant (right).
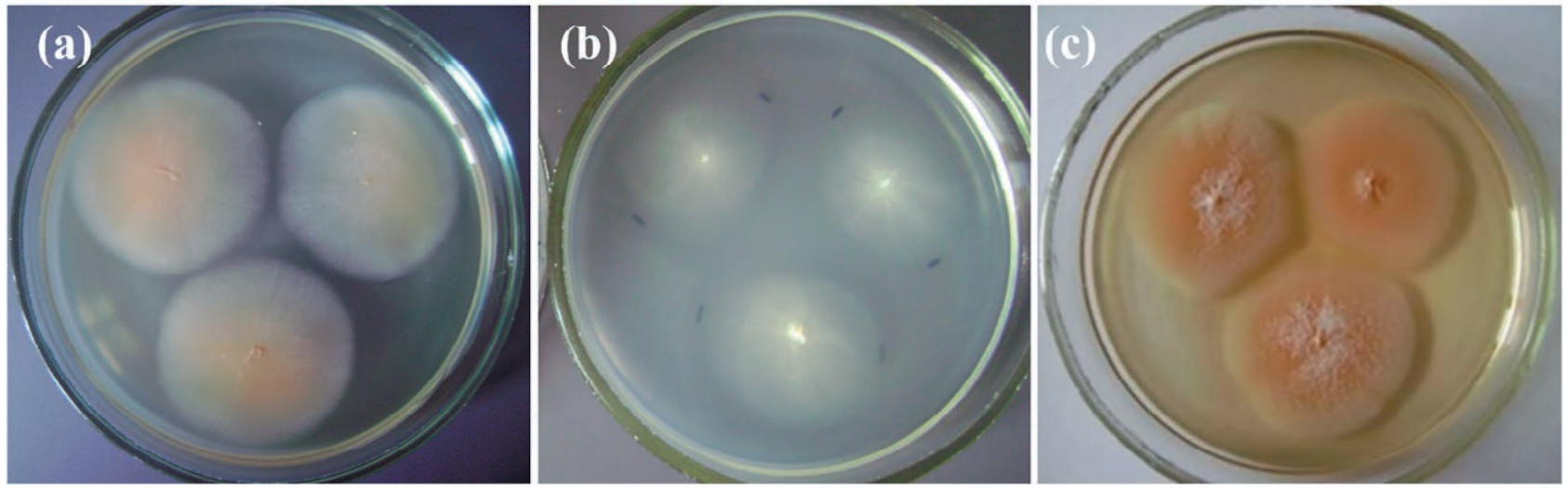

Figure 2. Colonies of Plectosphaerella melonis (isolate 502) on (a) PDA, (b) CZA, and (c) BMA. 
Table 1. Mean diameters of Plectosphaerella melonis (isolate 502) colonies on different nutrient media.

\begin{tabular}{lcc}
\hline Nutrient medium & $\begin{array}{c}\text { Mean colony diameter Mean colony diameter } \\
(\mathrm{mm}) \text { after } 7 \mathrm{~d} .\end{array}$ & $(\mathrm{mm})$ after 10 d. \\
\hline BMA & $20.2 \pm 0.2 \mathrm{c}$ & $26.8 \pm 0.1 \mathrm{c}$ \\
CZA & $17.1 \pm 0.1 \mathrm{~b}$ & $28.5 \pm 0.3 \mathrm{~b}$ \\
PDA & $21.2 \pm 0.3 \mathrm{a}$ & $33.0 \pm 0.3 \mathrm{a}$ \\
\hline
\end{tabular}

The values are means \pm standard errors for three replicates.

Means in each column followed by different letters are significantly different ( $P \leq 0.05$; Mann-Whitney test).

Table 2. Mean Plectosphaerella melonis (isolate 502) colony diameters and growth rates at different temperatures.

\begin{tabular}{lcc}
\hline Temperature $\left({ }^{\circ} \mathrm{C}\right)$ & $\begin{array}{c}\text { Mean colony diameter } \\
(\mathrm{mm}, \text { after } 10 \mathrm{~d})\end{array}$ & $\begin{array}{c}\text { Mean colony radial } \\
\text { growth rate }\left(\mathrm{mm} \mathrm{h}^{-1}\right)\end{array}$ \\
\hline 10 & $5.5 \pm 0.3 \mathrm{~d}$ & $0.023 \pm 0.001 \mathrm{~d}$ \\
18 & $13.2 \pm 0.5 \mathrm{~b}$ & $0.055 \pm 0.002 \mathrm{~b}$ \\
26 & $22.3 \pm 0.3 \mathrm{a}$ & $0.093 \pm 0.001 \mathrm{a}$ \\
35 & $8.8 \pm 0.3 \mathrm{c}$ & $0.037 \pm 0.001 \mathrm{c}$ \\
\hline
\end{tabular}

The values are means \pm standard errors for three replicates.

Means in each column followed by different letters are significantly different ( $P \leq 0.05$; Duncan's multiple range test).

The optimum temperature growth for isolate 502 was $26^{\circ} \mathrm{C}$ (Table 2).

Isolate 502 was deposited at the Depository of the Institute of Microbiology and Virology, NAS of Ukraine, with the number IMB F-100138.

Morphological identification of the isolate was confirmed by the molecular analysis. The sequence of isolate 502 was determined and submitted to GenBank with accession number MK736305.1. The BLASTn analysis showed $99 \%$ similarity with 14 strains of A. cucurbitacearum and $P$. melonis.

Pathogenicity of $P$. melonis 502 to cucumber plants was confirmed. Symptoms of root system damage were observed after 14 days for cucumber plants grown in soil inoculated with this isolate (Figure 3). The cucumber variety Nizhynskyi 12 was very sensitive to the pathogen at the two true leaf growth stage (after 2 weeks from sowing) (Figure 3c). Above-ground symptoms were absent after $14 \mathrm{~d}$, although severe symptoms were apparent on the root system at this time. Investigating the sensitivity of cucurbit species to Spanish P. melonis isolates, Armengol et al. (1998) found that cucumber plants ranged from resistant to very susceptible, and that, in field conditions, cucumber plants were less affected by $P$. melonis than melon plants with the same level of susceptibility. In contrast, Bruton et al. (2000b), in studies of

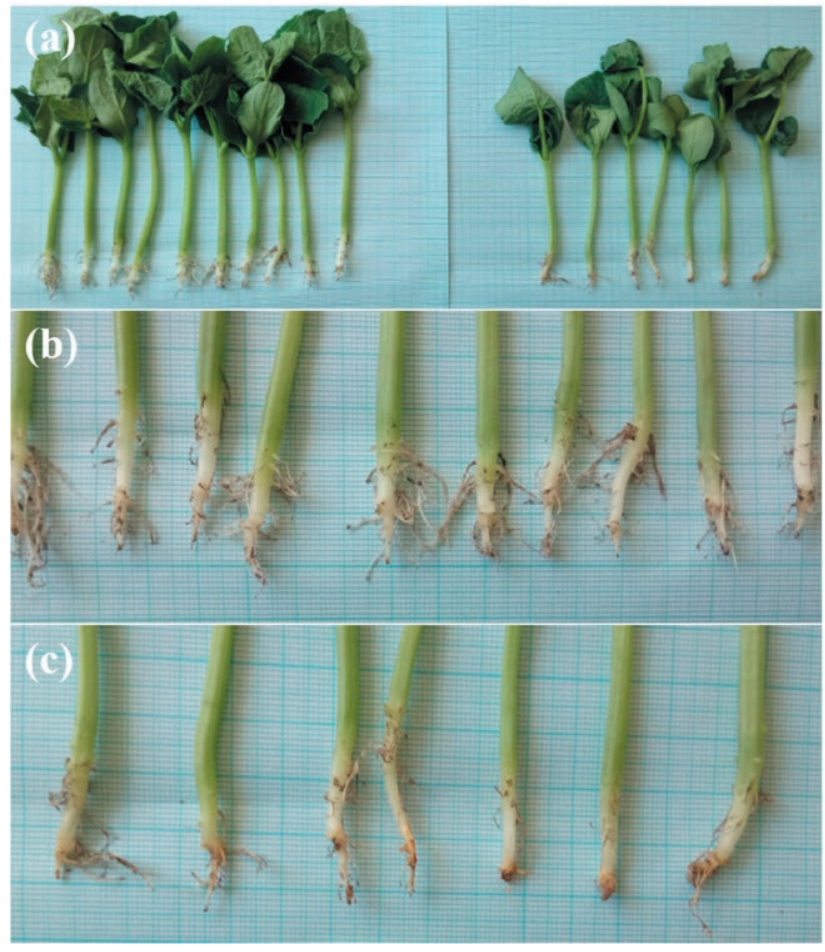

Figure 3. Healthy cucumber variety Nizhynskyi 12 plants (a - left, and $\mathrm{b}$ ), and diseased plants ( $\mathrm{a}$ - right, and c), after $14 \mathrm{~d}$ of cultivation.

pathogenicity of American P. melonis isolates, concluded that cucumber plants belonged to a high-resistance host group.

The present results are the first to show pathogenicity of $P$. melonis on cucumber plants in Ukraine. This study has confirmed the pathogenicity of this fungus to cucumber, and has shown that young cucumber seedlings were very susceptible to this pathogen.

\section{ACKNOWLEDGEMENTS}

The authors express gratitude to Senior Research Fellow, PhD Stanislav Nadkernichnyi for his academic advice in conducting the research described in this paper and his critical analysis of the research results. This research was carried out within the tasks of applied research No. 0116U003070.

\section{LITERATURE CITED}

Alfaro-García A., Armengol J., Bruton B.D., Gams W., García-Jiménez J., Martínez-Ferrer G., 1996. The taxonomic position of the causal agent of Acremonium collapse. Mycologia 88: 804-808. 
Armengol J., Sanz E., Martínez-Ferrer G., Sales R., Bruton B.D., García-Jiménez J., 1998. Host range of Acremonium cucurbitacearum, cause of Acremonium collapse of muskmelon. Plant Pathology 47: 29-35.

Birnboim H.C., Doly J., 1979. A rapid alkaline extraction procedure for screening recombinant plasmid DNA. Nucleic Acids Research 7(6): 1513-1523, DOI: 10.1093/NAR/7.6.1513.

Bruton B.D., Miller M.E., Garcia-Jimenez J., 1996. Comparison of Acremonium sp. from the Lower Rio Grande Valley of Texas with Acremonium sp. from Spain. Phytopathology 3: 86.

Bruton B.D., Garcia-Jimenez J., Armengol J., Popham T.W., 2000a. Assessment of virulence of Acremonium cucurbitacearum and Monosporascus cannonballus on Cucumis melo. Plant Disease 84: 907-913.

Bruton B.D., Popham T.W., García-Jiménez J., Armengol J., Miller M.E., 2000b. Disease reaction among selected Cucurbitaceae to an Acremonium cucurbitacearum isolate from Texas. Hortscience 35 (4): 677-680.

Carlucci A., Raimondo M.L., Santos J., Phillips A.J.L., 2012. Plectosphaerella species associated with root and collar rots of horticultural crops in southern Italy. Persoonia - Molecular Phylogeny and Evolution of Fungi 28(1): 34-48.

Chi M.H., Park S.Y., Lee Y.H. 2009. A quick and safe method for fungal DNA extraction. Plant Pathology Journal 25: 108-111.

Chowdhury E.H., Akaike T. 2005. Rapid isolation of high quality, multimeric plasmid DNA using zwitterionic detergent. Journal of Biotechnology 119(4): 343-347, DOI: 10.1016/J.JBIOTEC.2005.05.013.

Garrido C., Carbú M., Fernández-Acero F. J., Boonham N., Colyer A., Cantoral J. M., Budge G., 2009. Development of protocols for detection of Colletotrichum acutatum and monitoring of strawberry anthracnose using real-time PCR. Plant Pathology 58: 43-51, DOI: 10.1111/J.1365-3059.2008.01933.X.

Perth S.J., 1978. Fundamentals of the Cultivation of Microorganisms and Cells. World, Moscow, Russia, 330 pp (in Russian).

Raimondo M.L., Carlucci A., 2018a. Characterization and pathogenicity of Plectosphaerella spp. collected from basil and parsley in Italy. Phytopathologia Mediterranea 57 (2), 284-295.

Raimondo M.L., Carlucci A., 2018b. Characterization and pathogenicity assessment of Plectosphaerella species associated with stunting disease on tomato and pepper crops in Italy. Plant Pathology 67 (3), 626-641.

Sika K.C., Kefela T., Adoukonou-Sagbadja H., Ahoton L., Saidou A., ... Gachomo E. W. 2015. A simple and efficient genomic DNA extraction protocol for large scale genetic analyses of plant biological systems. Plant Gene 1: 43-45.

Watts D., MacBeath J. R. 2001. Automated fluorescent DNA sequencing on the ABI PRISM 310 Genetic Analyzer. Methods in Molecular Biology (Clifton, N.J.) 167: 153-170, DOI: 10.1385/1-59259-113-2:153

White T.J., Bruns T.D., Lee S.B., Taylor J.W., 1990. Amplification and direct sequencing of fungal ribosomal RNA genes for phylogenetics. In: PCR Protocols: a Guide to Methods and Applications (M.A. Innis, D.H. Gelfand, J.J. Sninsky, T.J. White, ed.), Academic Press, New York, USA, 315-321. 